\title{
Temperature and pH Dependent Deactivation of Cutinases from Thermobifida fusca: A Comparative Study of Homologous Enzymes
}

\author{
Krishnamoorthy Hegde, Venkata Dasu Veeranki* \\ Biochemical Engineering Laboratory, Department of Biotechnology, Indian Institute of Technology Guwahati, \\ Guwahati, India \\ Email: ${ }^{*}$ veeranki@iitg.ernet.in
}

Received 27 July 2014; revised 27 August 2014; accepted 12 September 2014

Copyright (C) 2014 by authors and Scientific Research Publishing Inc.

This work is licensed under the Creative Commons Attribution International License (CC BY). http://creativecommons.org/licenses/by/4.0/

c) (i) Open Access

\begin{abstract}
Thermostability of two homologous cutinases, Cut1 and Cut2 from Thermobifida fusca NRRL B-8184 was investigated at combination of different $\mathrm{pH}$ and temperature in the range of pH 6 - 9 and temperature $45^{\circ} \mathrm{C}-80^{\circ} \mathrm{C}$, respectively. The deactivation rate constants, the half-life and thermodynamic parameters, viz., $\Delta H^{*}, \Delta S^{*}, \Delta G^{*}$ and activation energy kinetics of inactivation of the cutinases were assessed at different combinations of $\mathrm{pH}$ and temperature and compared. The optimal $\mathrm{pH}$ and temperature for the least degree of deactivation for Cut1 and Cut2 were found to be $8^{\circ} \mathrm{C}$ and $45^{\circ} \mathrm{C}$, respectively. The deactivation process was found to be faster at $\mathrm{pH} 6$ and 9 , with minimum deactivation at $\mathrm{pH} 8$ for both the cutinases. It was found that $\Delta S^{*}$ values are negative for both the enzymes and $\Delta H^{*}$ value of Cut2 was 1.5 fold higher than that of Cut1 in the range of pH studied. Cut2 was found to be thermodynamically more stable with 1.7 fold higher deactivation energy at pH 6 and 7 and 1.4 fold higher deactivation energy at pH 8 and 9 in comparison to Cut1.
\end{abstract}

\section{Keywords}

Cutinase, Thermal Deactivation, Thermostability, Thermodynamics

\section{Introduction}

The goal of enzyme technology is to attain the adequacy of stringent industrial requirements to make it better than any other alternative process. This, however, requires scrutinization of many desirable features of the

\footnotetext{
${ }^{*}$ Corresponding author.
}

How to cite this paper: Hegde, K. and Veeranki, V.D. (2014) Temperature and pH Dependent Deactivation of Cutinases from Thermobifida fusca: A Comparative Study of Homologous Enzymes. Modern Research in Catalysis, 3, 128-135. http://dx.doi.org/10.4236/mrc.2014.34016 
enzyme like, catalytic ability, stability and structural properties. One of the key parameter among such properties is thermal deactivation of enzyme under process condition, which is believed to be a significant factor in many biotechnological processes [1] and in long term processes carried out in a bioreactor. In many cases it will be the consequential factor in deciding on the industrial application of an enzyme. Expeditious inactivation may hinder efficiency of the process in spite of good catalytic ability of the enzyme. Thus, an insight of enzyme deactivation kinetics is essential for better understanding of relation between structure and function of enzymes to enhance the feasibility of biotechnological process [2]. Enzymes are inactivated by many ways by a process where the secondary, tertiary or quaternary structure of a protein changes without breaking covalent bonds or by chemical modification of functional groups of the active site [3]. The enzyme inactivation processes are influenced to a great extent by parameters like temperature, $\mathrm{pH}$, activators and inhibitors. Thus, the study of relationship between enzyme and the process environment is vital in order to accomplish the process manipulation and engineer protein structure. Furthermore, the values of thermodynamic parameters are also helpful in analyzing the stability of proteins.

Cutinase (EC 3.1.1.74) is a cutin hydrolytic enzyme that belongs to the family serine hydrolases [4]. Apart from its natural substrate cutin, they can act on multifarious substrates such as esters, long and short chain fatty acids, triglycerides, biopolymers and share some vital catalytic properties of lipase and esterase. Because of its unique catalytic nature, it is being considered as one of the industrially important enzymes. Some of the useful applications of cutinase include hydrolysis of fats and oils, degradation of synthetic polymers like polyethylene terephthalate [5] [6], biodegradation and detoxification of fatty acid based toxins [7], esterification and transesterification reactions [8]. It has a potential to be an efficient biocatalyst in the food industry for synthesis of flavors, petrochemical industry for synthesis of biodiesel and preparation of house-hold detergents [9]. Both fungal and bacterial species have been reported to produce cutinase [4] [10]-[15].

Thermobifida fusca is an aerobic, moderately thermophilic, filamentous soil bacterium that is a major degrader of plant cell walls in heated organic materials [16]. Recently, a few studies describing production, biochemical characterization and application of cutinase from $T$. fusca in various fields such as cotton scoring, degradation of polymeric substrates have been published [5] [6] [12] [17].

In our previous studies on biochemical properties of two homologous cutinases, Cut1 and Cut2 from $T$. fusca NRRL B-8184, we observed that both the cutinases are thermostable, active in a broad range of $\mathrm{pH}$ and highly resistant to many surfactant and organic solvents, which could have great biotechnological promise in many industrial applications [12]. Furthermore, our studies on biochemical and structural properties of these two homologous enzymes also revealed that despite of 93\% identity among them at amino acid level, they showed different substrate specificity, biochemical and biophysical properties [12] [18]. In addition, fluorescence and CD spectral analysis of the equilibrium unfolding behavior in presence denaturants also revealed that Cut2 is structurally more stable in comparison to Cut1 and the hydrophobicity and surface electrostatic properties of these two enzymes are different [18]. However, no information is available on thermodynamic properties of these enzymes, which indicates the importance of present thermodynamic study for these two enzymes.

Thus, the present work focuses on study of combined effect of $\mathrm{pH}$ and temperature on purified, recombinant cutinases from Thermobifida fusca NRRL B-8184. It also deals with deactivation kinetics and thermodynamic parameters $\left(\Delta H^{*}, \Delta S^{*}, \Delta G^{*}\right.$ and activation energy) of thermal deactivation.

\section{Materials and Methods}

\subsection{Chemicals}

All the chemicals used in this study were of analytical grade purchased from Sigma Aldrich Co. India. T. fusca cutinase, Cut 1 and Cut2 used in the present study was previously cloned into pET22b(+), expressed in E. coli BL21 (DE3), purified to homogeneity and characterized in our laboratory [12].

\subsection{Cutinase Assay}

Cutinase activity against p-nitrophenyl butyrate (pNPB) was determined according to the method described earlier [12].

\subsection{Thermal Deactivation Study}

In order to study the thermal stability of cutinase in different $\mathrm{pH}$, the enzyme was incubated at four different 
temperatures in the range of $45^{\circ} \mathrm{C}$ and $80^{\circ} \mathrm{C}$. The $\mathrm{pH}$ of buffer containing the purified enzyme was adjusted to four different levels, viz., 6.0, 7.0, 8.0 and 9.0. The enzyme samples were deactivated at various combinations of $\mathrm{pH}$ and temperature (Table 1). Aliquots of samples were collected at different intervals of time and were assayed for the residual enzyme activity by pNPB assay. All the experiments were performed in duplicates until and otherwise mentioned.

\subsubsection{Estimation of Deactivation Rate Constant}

The following first order expression was used to account for the zero activity at a particular temperature and at specified incubation time.

$$
\ln \left[\frac{E_{t}}{E_{0}}\right]=-k_{d} t
$$

where, $k_{d}$ is enzyme deactivation rate constant $\left(\mathrm{h}^{-1}\right) ; t$ is incubation time (h); $E_{t}$ is the enzyme activity (U/ml) at time $t$ and $E_{0}$ is initial enzyme activity $(\mathrm{U} / \mathrm{ml})$ at time $t=0$, The values of $k_{d}$ were calculated from the plot of $\ln \left(E_{t} / E_{0}\right)$ vs. $t$ at a particular temperature.

The half-life of an enzyme was defined as the time required by the enzyme to lose half of its initial activity and can be expressed by the following equation.

$$
t_{\frac{1}{2}}=\frac{\ln 2}{k_{d}}
$$

\subsubsection{Estimation of Thermodynamic Parameters for Cutinase Deactivation}

In order to obtain the change in enthalpies $\left(\Delta H^{*}\right)$ and change in entropies $\left(\Delta S^{*}\right)$ during enzyme deactivation

\begin{tabular}{|c|c|c|c|c|c|c|c|c|c|c|c|c|c|}
\hline \multirow{3}{*}{ pH } & \multirow{3}{*}{ Temperature } & \multicolumn{3}{|c|}{$k_{d}$} & \multicolumn{3}{|c|}{$t_{1 / 2}$} & \multicolumn{3}{|c|}{$k_{d}$} & \multicolumn{3}{|c|}{$t_{1 / 2}$} \\
\hline & & \multicolumn{3}{|c|}{$\left(h^{-1}\right)$} & \multicolumn{3}{|c|}{$\left(h^{-1}\right)$} & \multicolumn{3}{|c|}{$\left(h^{-1}\right)$} & \multicolumn{3}{|c|}{$\left(h^{-1}\right)$} \\
\hline & & \multicolumn{6}{|c|}{ Cut1 } & \multicolumn{6}{|c|}{ Cut2 } \\
\hline \multirow{4}{*}{6} & 45 & 0.06 & \pm & 0.004 & 11.514 & \pm & 0.151 & 0.048 & \pm & 0.005 & 14.411 & \pm & 0.361 \\
\hline & 55 & 0.07 & \pm & 0.007 & 9.973 & \pm & 0.547 & 0.066 & \pm & 0.003 & 10.471 & \pm & 0.374 \\
\hline & 70 & 0.098 & \pm & 0.010 & 7.091 & \pm & 0.289 & 0.152 & \pm & 0.004 & 4.566 & \pm & 0.400 \\
\hline & 80 & 0.169 & \pm & 0.013 & 4.094 & \pm & 0.052 & 0.25 & \pm & 0.007 & 2.771 & \pm & 0.545 \\
\hline \multirow{4}{*}{7} & 45 & 0.048 & \pm & 0.007 & 14.396 & \pm & 0.356 & 0.041 & \pm & 0.002 & 16.989 & \pm & 0.699 \\
\hline & 55 & 0.054 & \pm & 0.001 & 12.884 & \pm & 0.625 & 0.05 & \pm & 0.004 & 13.808 & \pm & 0.571 \\
\hline & 70 & 0.078 & \pm & 0.008 & 8.836 & \pm & 0.591 & 0.104 & \pm & 0.004 & 6.691 & \pm & 0.276 \\
\hline & 80 & 0.139 & \pm & 0.013 & 4.978 & \pm & 0.550 & 0.243 & \pm & 0.009 & 2.848 & \pm & 0.387 \\
\hline \multirow{4}{*}{8} & 45 & 0.045 & \pm & 0.004 & 15.369 & \pm & 0.022 & 0.039 & \pm & 0.006 & 17.593 & \pm & 0.349 \\
\hline & 55 & 0.052 & \pm & 0.004 & 13.215 & \pm & 0.152 & 0.045 & \pm & 0.003 & 15.541 & \pm & 0.325 \\
\hline & 70 & 0.075 & \pm & 0.007 & 9.205 & \pm & 0.074 & 0.113 & \pm & 0.005 & 6.15 & \pm & 0.601 \\
\hline & 80 & 0.154 & \pm & 0.010 & 4.505 & \pm & 0.216 & 0.232 & \pm & 0.016 & 2.983 & \pm & 0.342 \\
\hline \multirow{4}{*}{9} & 45 & 0.055 & \pm & 0.007 & 12.534 & \pm & 0.378 & 0.058 & \pm & 0.005 & 11.869 & \pm & 1.039 \\
\hline & 55 & 0.064 & \pm & 0.004 & 10.78 & \pm & 0.057 & 0.069 & \pm & 0.006 & 10.017 & \pm & 0.719 \\
\hline & 70 & 0.113 & \pm & 0.005 & 6.156 & \pm & 0.031 & 0.159 & \pm & 0.013 & 4.357 & \pm & 0.182 \\
\hline & 80 & 0.172 & \pm & 0.008 & 4.021 & \pm & 0.156 & 0.285 & \pm & 0.039 & 2.43 & \pm & 0.233 \\
\hline
\end{tabular}

Table 1. Effect of temperature at different $\mathrm{pH}$ on deactivation constant $\left(k_{d}\right)$ and half life time $\left(t_{1 / 2}\right)$ of Cut1 and Cut2.

Results are the average of two experiments with \pm SD. 
process, it is necessary to make use of the theory of absolute reaction rates [19] [20]. The central point of this theory is that the rate of any reaction at a given temperature depends only on the concentration of an energy-rich activated complex, which is in equilibrium with the inactivated reactants. The deactivation constant is expressed by the following equation.

$$
\ln \left(\frac{k_{d}}{T}\right)=\ln \left(\frac{\kappa}{h}\right)+\left(\frac{\Delta S^{*}}{R}\right)-\left(\frac{-\Delta H^{*}}{R}\right)\left(\frac{1}{T}\right)
$$

where, $k_{d}$ is enzyme deactivation rate constant $\left(\mathrm{h}^{-1}\right) ; \kappa$ is Boltzmann constant $\left(1.38 \times 10^{-23} \mathrm{~J} / \mathrm{K}\right)$; $h$ is Plank's constant $\left(6.626 \times 10^{-34} \mathrm{~J} \cdot \mathrm{s}\right) \Delta H^{*}$ is change in enthalpy $(\mathrm{J} / \mathrm{mol}) ; \Delta S^{*}$ is change in entropy $(\mathrm{J} / \mathrm{mol} / \mathrm{K}) ; R$ is gas constant $(8.314 \mathrm{~J} / \mathrm{M} / \mathrm{K})$ and $T$ is temperature $(\mathrm{K})$. The values of $\Delta H^{*}$ and $\Delta S^{*}$ were calculated from the slope and intercept of the plot of $\ln \left(k_{d} / T\right)$ versus $1 / T$, respectively. Values of change in free energy $\left(\Delta G^{*}\right)$ were further estimated by the following relationship.

$$
\Delta G^{*}=\Delta H^{*}-T \Delta S^{*}
$$

where, $\Delta G^{*}$ is change in free energy $(\mathrm{J} / \mathrm{mol})$.

The activation energy $\left(E_{A}\right)$ was calculated from the Arrhenius equation as:

$$
\ln k_{d}=\ln k_{0}-\left(\frac{E_{A}}{R}\right)\left(\frac{1}{T}\right)
$$

where, $E_{A}$ activation energy $(\mathrm{J} / \mathrm{mol})$ and $k_{0}$ is frequency factor $\left(\mathrm{h}^{-1}\right)$.

The values of $E_{A}$ and $k_{0}$ were estimated from the slope and intercept of the plot of $\ln \left(k_{d}\right)$ versus $1 / T$, respectively.

\section{Results and Discussion}

\subsection{Thermal Deactivation at Different $\mathrm{pH}$ and Temperature}

Cut1 and Cut2 were deactivated under various combinations of $\mathrm{pH}$ and temperature as discussed in "Materials and Methods". The extent of deactivation was measured by the deactivation rate. The deactivation rate is proportional to the active enzyme concentration (expressed in terms of specific activity), and $k_{d}$ (deactivation rate constant) is the proportional constant. The deactivation process was modeled as first-order kinetics and the deactivation rate constant was evaluated. The effect of temperature on half-life time has been studied and the results are shown in Table 1 for Cut 1 and Cut2. The minimum value of $k_{d}$ observed for Cut1 and Cut2 are 0.045/min and $0.039 / \mathrm{min}$, respectively. The combinations of $\mathrm{pH}$ and temperature at which the above mentioned minimum deactivation rate constant have been observed are $8{ }^{\circ} \mathrm{C}$ and $45^{\circ} \mathrm{C}$ for both Cut1 and Cut2. The deactivation process was found to be faster at $\mathrm{pH}$ below 7 and above 8 for both the cutinases. However, the rate of deactivation was faster for Cut1 in comparison to Cut2 (Table 1). According to the 2D electrophoresis, the pI of the Cut1 and Cut2 was determined to be 7.5 and 7.7, respectively (data not shown) thus, maximum stability was achieved close to the pI of the enzyme [21]. Similar observations have been made for cutinase from $F$. solani and other enzymes [21] [22]. At pH values above and below pI, the net charge may lead to an electrostatic destabilization of the protein, hence the lower thermal stability.

It was also observed that with increase in the temperature above $70^{\circ} \mathrm{C}$, the deactivation occurs faster, irrespective of $\mathrm{pH}$ for both the cutinases. Furthermore, the observation of interrelationship between conformational stability and enzyme activity suggested that in naturally occurring enzymes one cannot expect to find stability at temperatures far above than that of growth of an organism [23]. The results obtained in the present study also indicate that optimum $\mathrm{pH}$ and temperature lie near that of the growth condition.

It was found that maximum half-life time of Cut2 was $17.59 \mathrm{~h}$, showing that this enzyme is more stable than Cut1 (15.3 h) at optimum conditions of $\mathrm{pH}$ and temperature ( $\mathrm{pH} 8$ and $45^{\circ} \mathrm{C}$, respectively).

\subsection{Enthalpy and Activation Energy Change during Deactivation in Varying $\mathrm{pH}$}

In order to understand the behavior of enzyme molecules in different physiological conditions change in enthalpy $\left(\Delta H^{*}\right)$ and activation energy $\left(E_{A}\right)$ was investigated. In general, thermal denaturation of enzymes occurs in two steps i.e., where $\mathrm{N}$ is native enzyme, $\mathrm{U}$ is unfolded inactive enzyme which could be reversibly refolded upon 
cooling and I is inactivated enzyme formed after continuous exposure to heat for long time, which cannot be recover upon cooling [24] [25]. Enthalpy change and deactivation energy of Cut1 and Cut2 were calculated within a temperature range of $45^{\circ} \mathrm{C}$ to $80^{\circ} \mathrm{C}$. It has been reported that enthalpy change of enzymes should be in the range of 20 to $150 \mathrm{~kJ} \cdot \mathrm{mol}^{-1}$ [26]. As depicted in Table 2, $\Delta \mathrm{H}^{*}$ of Cut1 and Cut2 deactivation was within this value in the range of buffers studied at all the temperatures, which indicates that these enzymes maintained their rate of reaction even during incubation at different $\mathrm{pH}$ and temperatures. Furthermore, enthalpy of Cut1 and Cut2 increased as pH increased (Table 2) till pH 8. However, there was a decrease in enthalpy of Cut1 and Cut2 at $\mathrm{pH}$ 9. This result shows that both the cutinases were more stable at $\mathrm{pH} 7$ and 8 . However, it was interesting to observe that $\Delta \mathrm{H}^{*}$ value of Cut 2 was $\sim 1.5$ fold higher than Cut1 in the range of $\mathrm{pH}$ studied, which indicates that Cut2 is thermodynamically more stable than Cut1. Enthalpy derives from the energy of the non-covalent interactions within the polypeptide chain, the hydrophobic interactions, H-bonds and ionic bonds. Thus, the substantial difference in the enthalpy for Cut1 and Cut2 indicates that there is a considerable tertiary structural difference between Cut1 and Cut2. Similar structural stability difference was observed for these enzymes with guanidine hydrochloride based equilibrium unfolding studies [18].

The temperature dependency of first-order deactivation rate constant was studied by Arrhenius equation (Eq. 8). The activation energy $\left(E_{A}\right)$ estimated are shown in Table 2. It was observed that the deactivation energy is maximum at optimum $\mathrm{pH}$ for both Cut1 and Cut2, however, Cut2 showed $\sim 1.7$ fold higher deactivation energy at $\mathrm{pH} 6$ and 7 and $\sim 1.4$ fold higher deactivation energy at $\mathrm{pH} 8$ and 9 in comparison to Cut1 (Table 2). The higher deactivation energy suggests that Cut2 require more energy to get deactivated compare to Cut1. The differential thermodynamic properties of the two cutinases may be linked with surface electrostatic properties of the two enzymes and the dissimilarity in the N-terminal amino acid regions [18]. It has also been observed for the F. solani cutinase that N-terminal region has a crucial role in the unfolding of the cutinase [21] [27].

It has also been reported that unfavorable charge distribution on the surface of proteins is capable of destabilizing the protein [28]. Furthermore, the surface electrostatic interactions are believed to contribute positively to the protein stabilization by forming ionic interactions (salt bridges) between residues carrying opposite charges [21]. It has been observed that surface electrostatic properties of the two cutinases of $T$. fusca are fairly different and due to such differential properties these enzyme possess different stability and unfolding behavior in detergent, GdnHCl [18]. Thus, the difference in the stability of the two homologous proteins might be due to differential distribution of noncovalent electrostatic and hydrophobic interaction energies in Cut1 and Cut2.

Table 2. Estimated thermodynamic parameters during thermal deactivation for Cut1 and Cut2.

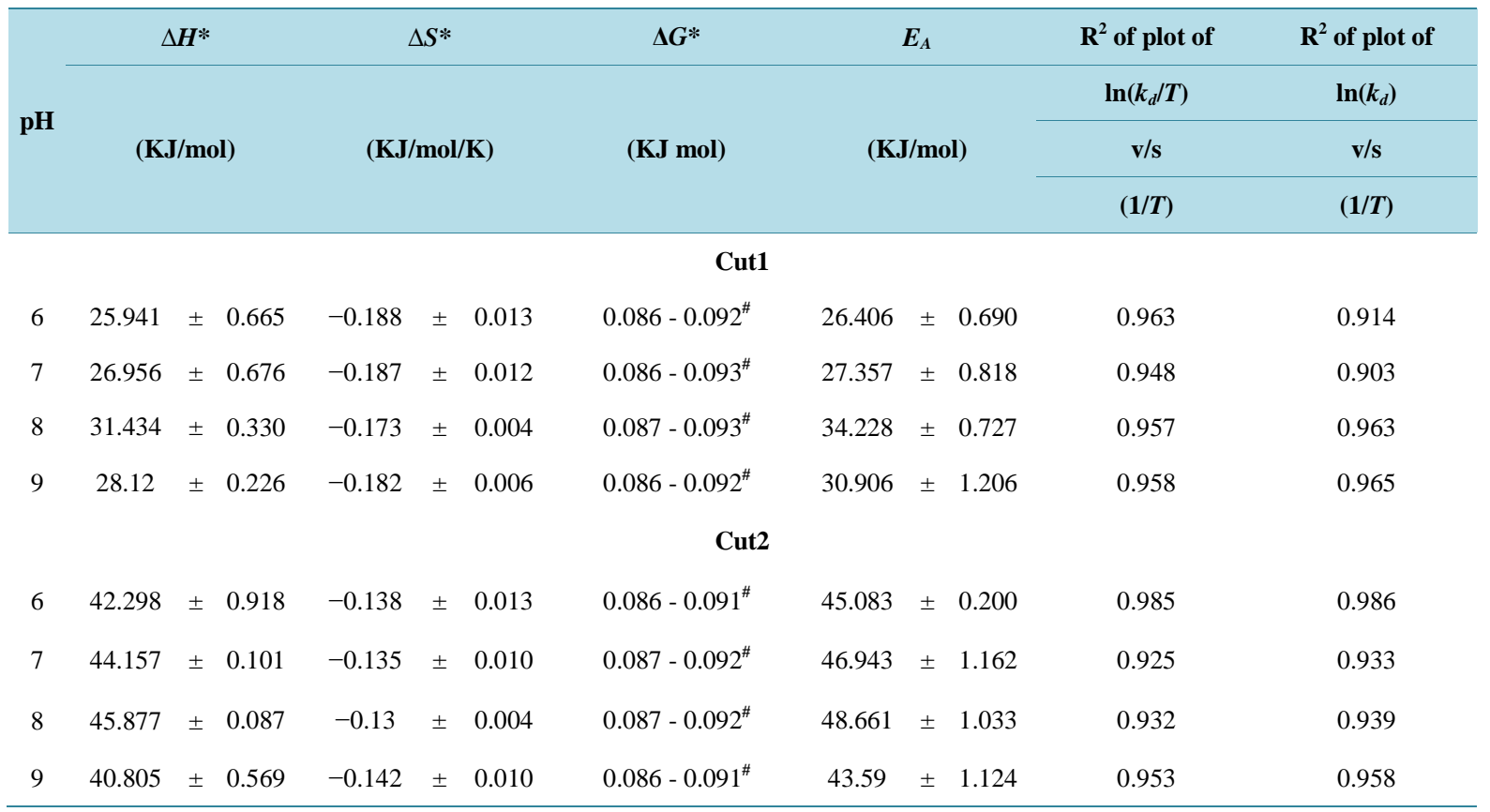

${ }^{\#}$ The temperature range is $45^{\circ} \mathrm{C}-80^{\circ} \mathrm{C}$, Results are the average of two experiments with $\pm \mathrm{SD}$. 


\subsection{Entropy and Free Energy Change during Deactivation in Varying pH}

The measurement of entropy change during unfolding of protein molecule is very much helpful in enhancing the thermostability of proteins of known 3-dimensional structure. This can be achieved by selective amino acid substitutions, which decreases the configurational entropy change of unfolding thereby increases the stability of the protein molecule [29]. In the present study, it was observed that the entropy values are negative for both the enzymes in all the cases (Table 2), which is unique in biocatalytic systems. The possible reason for negative entropy could be due to the formation of charged particles around the enzyme molecule and the ordering of solvent molecules or compaction of the enzyme molecules [25] [30]. Both Cut1 and Cut2 showed increase in entropy with increase in $\mathrm{pH}$ (Table 2). The probable reason is that enzyme gets unfolded during deactivation with the increase in $\mathrm{pH}$ or it may be due to the ordering of solvent molecules. Though the difference in the entropy change is marginal in the range of $\mathrm{pH}$ studied, apparently, Cut1 had lower entropy in comparison to Cut2. Furthermore, the negative $\Delta \mathrm{S}^{*}$ also signifies that the transition states of the cutinases were found to be ordered. Similar results have been observed for the amylase of Bacillus lichiniformis [31], the chitinase of T. harzianum [10] and the chitinase from Pantoea dispersa [25]. This result also indicates that cutinases were altered in the direction of partially unfolded transition state but the flexibility implies decreased conformational entropy of the folded state which is favorable to thermodynamic stability. Thus, it may be concluded on the basis of entropy that the mechanism of deactivation for Cut1 and Cut2 is more or less similar although the stability of Cut1 and Cut2 are different, with Cut2 to be thermodynamically more stable than Cut1.

Voordouw et al. (1976) [32] proposed that kinetic thermal stability should be used for defining thermostable enzymes. In addition, these authors emphasize that resistance of enzymes to thermal denaturation is due to the 'intrinsic' contribution of the polypeptide chain (i.e. hydrophobic interactions, hydrogen bonding and ionic stabilization). For both the cutinases, $\Delta \mathrm{G}^{*}$ increased with increasing temperature (Table 2). However, there was a marginal difference in $\Delta \mathrm{G}^{*}$ and both the cutinases showed almost similar free energy change with increasing temperature. Moreover, there was no or very small difference in the $\Delta \mathrm{G}^{*}$ value in the range of $\mathrm{pH}$ studied implies that $\mathrm{pH}$ had negligible effect on denaturing the enzymes or in other words; both the cutinases are active in broad $\mathrm{pH}$.

\section{Conclusion}

In the present study, the $\mathrm{pH}$ and temperature dependent thermal deactivation and thermodynamic properties of the cutinases from $T$. fusca have been elucidated to gain a new insight into the structure and functional relationship of the enzyme in view of its stability toward $\mathrm{pH}$ and temperature. The present study also demonstrated that two highly homologous cutinases show different thermodynamic behavior. Further, detailed structural and biophysical studies with differential scanning calorimetry and high resolution NMR and solving the crystal structure and biophysical analysis might shed light on the exact reason for these differences.

\section{Acknowledgements}

Authors acknowledge a financial support from DST through project for carrying out the experiments.

\section{References}

[1] Chitnis, A. and Sadana, A. (1989) pH-Dependent Enzyme Deactivation Models. Biotechnology and Bioengineering, 34, 804-818. http://dx.doi.org/10.1002/bit.260340610

[2] Sadana, A. (1995) Biocatalysis: Fundamentals of Deactivation Kinetics. Prentice-Hall, Englewood Cliffs.

[3] Joly, M (1965) Physico-Chemical Approach to the Denaturation of Proteins. Academic Press, New York.

[4] Purdy, R.E. and Kolattukudy, P.E. (1975) Hydrolysis of Plant Cuticle by Plant Pathogens_Purification, Amino-Acid Composition, and Molecular-Weight of 2 Isoenzymes of Cutinase and a Nonspecific Esterase from Fusarium solani f. pisi. Biochemistry, 14, 2824-2831. http://dx.doi.org/10.1021/bi00684a006

[5] Araujo, R., Silva, C., O’Neill, A., Micaelo, N., Guebitz, G., Soares, C.M., Casal, M. and Cavaco-Paulo, A. (2007) Tailoring Cutinase Activity towards Polyethylene Terephthalate and Polyamide 6.6 Fibers. Journal of Biotechnology, 128, 849-857. http://dx.doi.org/10.1016/j.jbiotec.2006.12.028

[6] Ribitsch, D., Yebra, A.O., Zitzenbacher, S., Wu, J., Nowitsch, S., Steinkellner, G., Greimel, K., Doliska, A., Oberdorfer, G., Gruber, C.C., Gruber, K., Schwab, H., Stana-Kleinschek, K., Acero, E.H. and Guebitz, G.M. (2013) Fusion of 
Binding Domains to Thermobifida cellulosilytica Cutinase to Tune Sorption Characteristics and Enhancing PET Hydrolysis. Biomacromolecules, 14, 1769-1776. http://dx.doi.org/10.1021/bm400140u

[7] Kim, Y.H., Ahn, J.Y., Moon, S.H. and Lee, J. (2005) Biodegradation and Detoxification of Organophosphate Insecticide, Malathion by Fusarium oxysporum f. sp. pisi Cutinase. Chemosphere, 60, 1349-1355. http://dx.doi.org/10.1016/j.chemosphere.2005.02.023

[8] Dutta, K. and Dasu, V.V. (2011) Synthesis of Short Chain Alkyl Esters Using Cutinase from Burkholderia cepacia NRRL B 2320. Journal of Molecular Catalysis B: Enzymatic, 72, 150-156. http://dx.doi.org/10.1016/j.molcatb.2011.05.013

[9] Dutta, K., Sen, S. and Veeranki, V.D. (2009) Production, Characterization and Applications of Microbial Cutinases. Process Biochemistry, 44, 127-134. http://dx.doi.org/10.1016/j.procbio.2008.09.008

[10] Egmond, M.R. and Vlieg, J.D. (2000) Fusarium solani pisi Cutinase. Biochimie, 82, 1015-1021. http://dx.doi.org/10.1016/S0300-9084(00)01183-4

[11] Fett, W.F., Gerard, H.C., Moreau, R.A., Osman, S.F. and Jones, L.E. (1992) Screening of Nonfilamentous Bacteria for Production of Cutin-Degrading Enzymes. Applied and Environmental Microbiology, 58, 2123-2130.

[12] Hegde, K. and Veeranki, V.D. (2013) Production Optimization and Characterization of Recombinant Cutinases from Thermobifida fusca sp. NRRL B-8184. Applied Biochemistry and Biotechnology, 170, 654-675. http://dx.doi.org/10.1007/s12010-013-0219-x

[13] Dutta, K., Krishnamoorthy, H. and Dasu, V.V. (2013) Novel Cutinase from Pseudomonas cepacia NRRL B 2320: Purification, Characterization and Identification of Cutinase Encoding Genes. The Journal of General and Applied Microbiology, 59, 171-184.

[14] Maeda, H., Yamagata, Y., Abe, K., Hasegawa, F., Machida, M., Ishioka, R., Gomi, K. and Nakajima, T. (2005) Purification and Characterization of a Biodegradable Plastic-Degrading Enzyme from Aspergillus oryzae. Applied Microbiology and Biotechnology, 67, 778-788. http://dx.doi.org/10.1007/s00253-004-1853-6

[15] Skamnioti, P., Furlong, R.F. and Gurr, S.J. (2008) Evolutionary History of the Ancient Cutinase Family in Five Filamentous Ascomycetes Reveals Differential Gene Duplications and Losses and in Magnaporthe grisea Shows Evidence of Sub- and Neo-Functionalization. New Phytologist, 180, 711-721. http://dx.doi.org/10.1111/j.1469-8137.2008.02598.x

[16] Bellamy, W.D. (1977) Cellulose and Lignocellulose Digestion by Thermophilic Actinomycetes for Single Cell Protein Production. Developments in Industrial Microbiology, 18, 249-254.

[17] Degani, O., Gepstein, S. and Dosoretz, C.G. (2002) Potential Use of Cutinase in Enzymatic Scouring of Cotton Fiber Cuticle. Applied Biochemistry and Biotechnology, 102, 277-289. http://dx.doi.org/10.1385/ABAB:102-103:1-6:277

[18] Hegde, K. and Veeranki, V.D. (2014) Structural Stability and Unfolding Properties of Cutinases from Thermobifida fusca. Applied Biochemistry and Biotechnology, 174, 803-819. http://dx.doi.org/10.1007/s12010-014-1037-5

[19] Eyring, H. and Stearn, A.E. (1939) The Application of the Theory of Absolute Reaction Rates to Proteins. Chemical Review, 24, 253-270. http://dx.doi.org/10.1155/S1110724301000249

[20] Kapat, A. and Panda, T. (1997) pH and Thermal Stability Studies of Chitinase from Trichoderma harzianum: A Thermodynamic Consideration. Bioprocess Engineering, 16, 269-272. http://dx.doi.org/10.1007/s004490050321

[21] Petersen, S.B., Fojan, P., Petersen, E.I. and Petersen, M. (2001) The Thermal Stability of the Fusarium solani pisi Cutinase as a Function of pH. Journal of Biomedicine and Biotechnology, 1, 62-69. http://dx.doi.org/10.1155/S1110724301000249

[22] Relkin, P. (1996) Thermal Unfolding of $\beta$-Lactoglobulin, $\alpha$-Lactalbumin, and Bovine Serum Albumin: A Thermodynamic Approach. International Journal of Food Sciences and Nutrition, 36, 556-601.

[23] Daniel, R.M. (1996) The Upper Limits of Enzyme Thermal Stability. Enzyme and Microbial Technology, 19, 74-79. http://dx.doi.org/10.1016/0141-0229(95)00174-3

[24] Eisenberg, H., Mevarech, M. and Zaccai, G. (1992) Biochemical, Structural, and Molecular Genetic Aspects of Halophilism. Advances in Protein Chemistry, 43, 1-62. http://dx.doi.org/10.1016/S0065-3233(08)60553-7

[25] Gohel, V. and Naseby, D.C. (2007) Thermalstabilization of Chitinolytic Enzymes of Pantoea dispersa. Biochemical Engineering Journal, 35, 150-157. http://dx.doi.org/10.1016/j.bej.2007.01.009

[26] D’Amico, S., Marx, J.C., Gerday, C. and Feller, G. (2003) Activity-Stability Relationships in Extremophilic Enzymes. Journal of Molecular Biology, 278, 7891-7896.

[27] Ternstrom, T., Svendsen, A., Akke, M. and Adlercreutz, P. (2005) Unfolding and Inactivation of Cutinases by AOT and Guanidine Hydrochloride. Biochimica et Biophysica Acta (BBA), Proteins and Proteomics, 1748, 74-83.

[28] Loladze, V.V., Ibarra-Molero, B., Sanchez-Ruiz, J.M. and Makhatadze, G.I. (1999) Engineering a Thermostable Protein via Optimization of Charge-Charge Interactions on the Protein Surface. Biochemistry, 38, 16419-16423. 
http://dx.doi.org/10.1021/bi992271w

[29] Declerck, N., Machius, M., Joyet, P., Wiegand, G., Huber, R. and Gaillardin, C. (2002) Hyperthermostabilization of Bacillus licheniformis $\alpha$-Amylase and Modulation of Its Stability over a $50^{\circ} \mathrm{C}$ Temperature Range. Protein Engineering, Design and Selection, 16, 287-293. http://dx.doi.org/10.1093/proeng/gzg032

[30] Gummadi, S.N. (2003) What Is the Role of Thermodynamics on Protein Stability? Biotechnology and Bioprocess Engineering, 8, 9-18. http://dx.doi.org/10.1007/BF02932892

[31] Foster, R.L. (1980) Modification of Enzyme Activity. Croom Helm, London.

[32] Voordouw, G., Milo, C. and Roche, R.S. (1976) Role of Bound Calcium Ions in Thermostable, Proteolytic Enzymes. Separation of Intrinsic and Calcium Ion Contributions to the Kinetic Thermal Stability. Biochemistry, 15, 3716-3724. http://dx.doi.org/10.1021/bi00662a012 
Scientific Research Publishing (SCIRP) is one of the largest Open Access journal publishers. It is currently publishing more than 200 open access, online, peer-reviewed journals covering a wide range of academic disciplines. SCIRP serves the worldwide academic communities and contributes to the progress and application of science with its publication.

Other selected journals from SCIRP are listed as below. Submit your manuscript to us via either submit@scirp.org or Online Submission Portal.
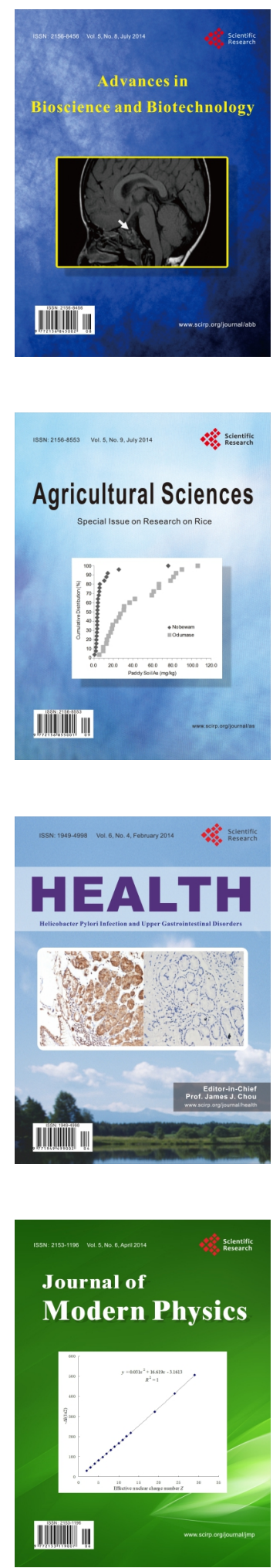
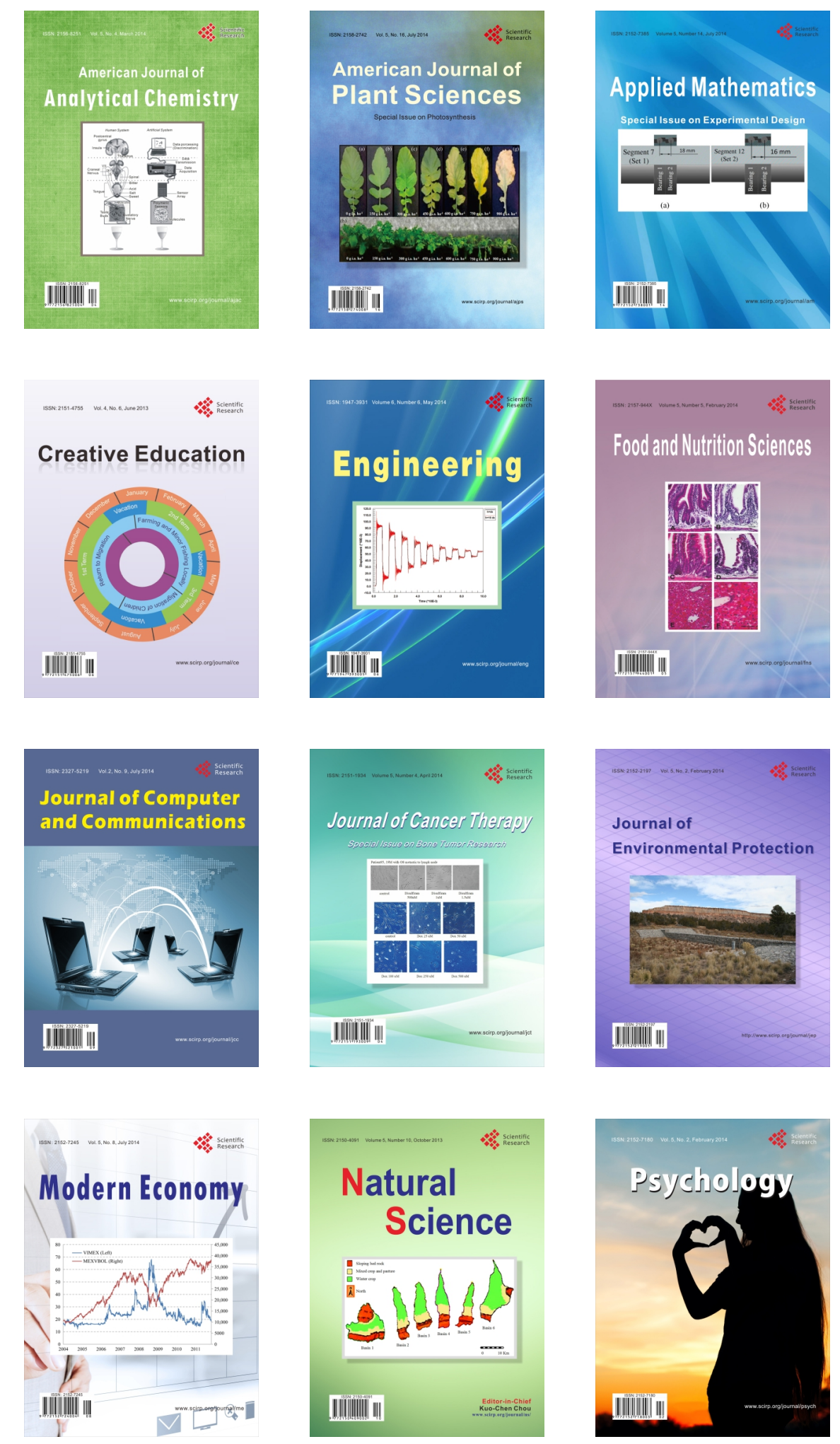